\title{
Disturbance increases high tide travel distance of a roosting shorebird but only marginally affects daily energy expenditure
}

Hans Linssen ${ }^{1,2^{*}}$, Martijn van de Pol ${ }^{1,3}$, Andrew M. Allen ${ }^{3,4}$, Mitzi Jans ${ }^{1}$, Bruno J. Ens ${ }^{3,5}$, Karen L. Krijgsveld ${ }^{6}$, Magali Frauendorf ${ }^{1,3}$ and Henk-Jan van der Kolk ${ }^{1,3}$

\begin{abstract}
Background: Anthropogenic disturbance can negatively affect an animal's energy budget by evoking movement responses. Existing research focuses mainly on immediate displacement as a disturbance effect, since this can be easily observed in the field. However, effects on movement over longer timescales are poorly examined and it is largely unknown if and to what extent they reflect immediate responses. Longer-term responses could for example be larger than immediate responses if birds, after disturbance, return to the original location and thereby travel twice the immediate disturbed distance.

Methods: We combined GPS tracking data with observational data to quantify the effects of anthropogenic (air force and walkers) and non-anthropogenic disturbances on distances travelled by roosting Eurasian Oystercatchers (Haematopus ostralegus) during the non-breeding season. We compared immediate displacement after a disturbance with distance travelled during the entire high tide period (longer-term response), while accounting for environmental factors. Additionally, we calculated energy expenditure due to disturbance based on observed disturbance frequencies.

Results: Disturbance resulted in an immediate displacement response of $\sim 200 \mathrm{~m}$ (median). Air force disturbances tended to yield larger immediate responses than walker and, especially, than non-anthropogenic disturbances. Longer-term responses and immediate responses were approximately similar, suggesting that, over longer timescales, spatial disturbance effects in the study area remain confined to immediate effects. However, disturbances were infrequent (0.17 disturbances per bird per hour) and most disturbances were of natural origin (62\%). Consequently, anthropogenic disturbance of roosting oystercatchers in the study area on average costs $0.08 \%$ of the daily energy expenditure.

Conclusions: Our results suggest that immediate spatial responses to disturbance can be a useful proxy for spatial responses over longer timescales. Over the non-exhaustive range of conditions investigated, energetic consequences of spatial disturbance responses for an oystercatcher in the study area are marginal due to low disturbance levels.
\end{abstract}

Keywords: Biologging, Disturbance, Haematopus ostralegus, High tide roost, Movement ecology, Shorebird

\footnotetext{
*Correspondence: Hans.Linssen@wur.nl

${ }^{2}$ Resource Ecology Group, Wageningen University \& Research, 6708PB Wageningen, The Netherlands

Full list of author information is available at the end of the article
} 


\section{Background}

Anthropogenic disturbance can negatively impact a bird's energy budget by evoking energetically costly responses such as increased movement (e.g. Stillman and GossCustard 2002; Collop et al. 2016), physiological changes (Ackerman et al. 2004; Walker et al. 2005) and deviations from optimal foraging patterns (Gill et al. 1996). Immediate flight responses have proved the most accessible indicator of the impact of disturbance (Gill 2007) as they are relatively straightforward to measure in the field through observation.

Flight initiation distances (i.e. the distance at which a bird takes flight when approached by a disturbance source) have been determined for a range of species and disturbance sources in both experimental and observational studies (e.g. Fitzpatrick and Bouchez 1998; Lord et al. 2001; Stillman and Goss-Custard 2002; Glover et al. 2011; Collop et al. 2016). Flight distances (i.e. the distance travelled after disturbance) and flight time are reported in fewer studies (e.g. Kirby et al. 1993; Spaans et al. 1996; Beale and Monaghan 2004; Collop et al. 2016), likely because these responses are difficult to quantify when birds fly for longer distances after being disturbed.

Longer-term disturbance effects on the individual (and subsequently on the population) level cannot be straightforwardly deduced from immediate responses without knowledge of spatial behaviour after the immediate response (Nisbet 2000; Gill et al. 2001; Gill 2007). For example, for birds that follow a trajectory during high tide dictated by waterline fluctuation, disturbance does not necessarily incur extra flight distance compared to their normal trajectory if the disturbance causes them to move along that trajectory. On the other hand, immediate spatial responses could be aggravated over the longer term when birds deviate from their normal spatial pattern and subsequently return to the initial location of disturbance (e.g. because their roosting or foraging area is located there). Furthermore, in those cases where longerterm shifts in spatial distribution of birds do occur (e.g. Klein et al. 1995; Finney et al. 2005; Martín et al. 2014), it is often unclear how they arose from small-scale individual movements and what the true role of disturbance was therein. For example, longer-term changes might actually depend on availability of suitable alternative habitats rather than susceptibility to disturbance (Gill 2007). Our current understanding of the impact of disturbance on shorebird populations is thus hampered by a lack of studies that link immediate individual and longer-term population spatial responses to disturbance.

Recent advances in the development of light-weight GPS tracking devices provide opportunities to precisely study immediate spatial responses to disturbance in a natural context, while also following individuals over longer timescales, such as a high tide period, after being disturbed. This allows for assessing whether field observations of immediate disturbance responses are a useful proxy for longer-term responses. Thereby, GPS tracking provides an important step in understanding to what extent and how immediate spatial disturbance responses translate to additional costs in an individual's daily energy budget, and eventually to changes in longer-term individual movement and survival.

Here, we applied GPS tracking technology to study both immediate and longer-term spatial disturbance responses of roosting Eurasian Oystercatchers (Haematopus ostralegus) in the Wadden Sea. The Wadden Sea, because of its key location in the East-Atlantic flyway and its high food availability, is an important stop-over and wintering ground for shorebirds (e.g. van de Kam et al. 1999; Reineking and Sudbeck 2006; van Roomen et al. 2017). Yet, the area is under increasing pressure of year-round anthropogenic disturbance by military, commercial and recreational activities (Hofstede et al. 2004; Brandt et al. 2009; Laursen et al. 2009; Bjarnason et al. 2017; Blew et al. 2017). The oystercatcher is one of the most threatened shorebirds in the Wadden Sea: the average population in the area has more than halved since the 1990s (Blew et al. 2016; Koffijberg et al. 2017) and is still declining for reasons as of yet not well understood (for an overview, see van de Pol et al. 2014). Disturbance has been put forward as one of the drivers of the decline, but its relevance remains largely unexplored (van de Pol et al. 2014).

We quantified the spatial effect of various types of disturbance on two temporal scales: immediate displacement (short-term) and distance travelled during an entire high tide period (longer-term). To identify disturbance events, we observed groups of oystercatchers (among which were birds equipped with GPS trackers) on the Dutch Wadden Sea island of Vlieland, which is exposed to regular military air force training and some recreation. We linked disturbances observed in the field to GPS-tracked movements in order to investigate to what extent high tide travel distance is determined by immediate spatial responses to disturbance, and how this effect compares to the effect of natural sources of environmental variation. Finally, by combining the observed disturbance frequencies and GPS-tracked travel distances with estimates of flight energetics from the literature, we estimated the impact of disturbance on the daily energy budget of oystercatchers in our study area.

\section{Methods}

\section{Study system}

The study was conducted in the tidal area on the southern side of the Vliehors $\left(53^{\circ} 14^{\prime} \mathrm{N}, 4^{\circ} 57^{\prime} \mathrm{E}\right)$. The Vliehors is 


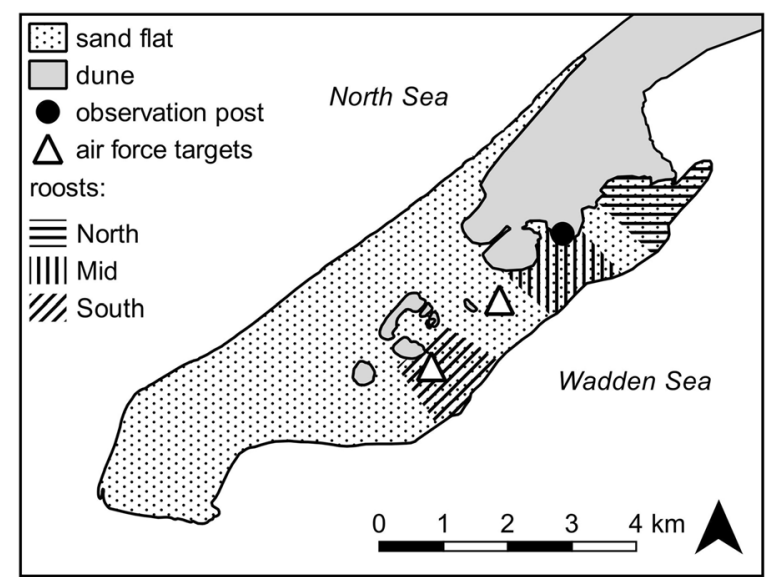

Fig. 1 Schematic map of the Vliehors, showing locations of the three high tide roosts that constituted the study area, the location of the observation post and the primary air force shooting and bombing locations

a sand flat located at the south-western tip of Vlieland, a barrier island in the Dutch part of the Wadden Sea (Fig. 1). The Vliehors has three established high tide roosts for oystercatchers, located roughly $2 \mathrm{~km}$ apart from each other on the sand flat and unseparated by geographical boundaries. We hereafter refer to these roosts as North, Mid and South (Fig. 1). Numbers of oystercatchers in the study area are highest from July until February, when young birds and local breeding birds (which stay year-round) are accompanied by wintering migratory birds that breed elsewhere. During this period, up to 5000 oystercatchers may roost in the Vliehors area during high tide. The area has been used as a military air force training ground since 1948. Military training occurs during weekdays and the area is accessible for civilians only on weekends. Military training comprises flying and targeted shooting and bombing by jet fighters, flying, landing and targeted shooting by helicopters and occasional exercises with other airplanes. During our 100 day observation period there were 51 training days, with on average $2.3 \mathrm{~h}$ of training per training day. Almost all training occurs during daylight with only occasional exercises in the early evening.

\section{Disturbance data}

Observations took place outside the breeding season between 3rd August and 10th November 2017. During that period, we observed oystercatchers at their high tide roosts from an observation post using binoculars $(8-10 \times$ magnification) and telescopes (maximum 60-75× magnification) for a total of $181 \mathrm{~h}$ during 61 high tide periods, in time windows reaching from some hours before high tide (mean $\pm \mathrm{SD}=1.1 \pm 1.8 \mathrm{~h}$ ) until some hours after (mean $\pm \mathrm{SD}=2.0 \pm 2.0 \mathrm{~h}$ ). Time window extent was limited usually by sunrise or sunset. Three geographic polygons were set to mark the boundaries of the roost sites in our study (Fig. 1). Due to weather conditions (sun, wind and rain), not all three roosts could always be simultaneously observed; of the 61 high tide periods, we observed roosts North, Mid and South for 45, 59 and 29 periods, respectively.

During observations, we scored all flying and prolonged walking movements in groups of roosting oystercatchers that were initiated by anthropogenic or non-anthropogenic disturbances. These included disturbances by unknown sources, wherein birds suddenly flew up to settle down again after some displacement, in a manner similar to reacting upon being disturbed by an identifiable source. We interpreted those as disturbances by non-anthropogenic sources. For each bird movement we scored (1) disturbance source, (2) time at the start of movement, (3) number of individuals constituting the movement, (4) location at the start of movement and (5) location at the end of movement.

As disturbances were scarce, we experimentally disturbed groups of birds approximately twice per observation round (total $n=118$ ). One observer would walk towards the roosting oystercatchers, at random times and following alternate trajectories, until the birds took flight. These disturbances were documented like any other, and included in the analysis as disturbance by walkers.

Additionally, we carried out hourly counts of birds present in the study area during each observation round. From these counts, we calculated bird-hours (average number of birds present during the observation round multiplied by the duration of the round), which we used to calculate average disturbance frequencies per individual bird (number of disturbed birds divided by bird-hours).

\section{GPS data}

Twenty wintering oystercatchers (six juveniles, six subadults and eight adults) were caught on the Vliehors using mist nets and equipped with solar powered GPS tracking devices (UVA-BiTS; Bouten et al. 2013) in the period between 2nd and 19th December 2016 (one individual on 19th January 2017). Another 20 adult local breeding birds were caught with walk-in nest traps and equipped with GPS trackers between 11th May and 18th July 2017. The trackers were mounted on the birds' backs using a wing harness with Teflon ribbons connected around the neck and both wings in a figure eight configuration (Thaxter et al. 2014; Fig. 4). Tracker (13.5 g) and harness $(2 \mathrm{~g})$ together weighed $2.6 \%$ of the average bird body mass. Twenty-one out of 40 birds that were tagged provided the GPS data used in this study. As data are 
downloaded from the trackers by antennae in the study area, we are unsure whether birds that did not provide data $(n=19)$ had tracker malfunction, emigrated or died. Future analyses may be able to estimate tracker-related mortality by comparing survival of GPS tracked and colour-ringed oystercatchers in the study area.

The trackers measured location with 288-s ("5-min") intervals. Some trackers also measured location in short bursts of 16-s intervals for a maximum of $2 \mathrm{~h}$ per day. These 16-s interval bursts were converted to 5 -min interval bouts by deleting the last 17 out of every 18 measurements. We used these converted bouts together with the original 5-min interval bouts for the analysis.

To link the observed disturbances to the GPS data, we digitised the observed disturbances of flocks (representing each movement with a single line) and overlaid those lines spatially and temporally with individual bird GPS tracks on a satellite map. Then we labelled individual GPS measurements from the GPS tracks as "undisturbed" or "disturbed", in the latter case including the disturbance source. In the field, we observed that displacements after disturbance were often approximately linear and that undisturbed birds generally move very little within a five-minute interval (see Results). Consequently, even if disturbance displacements were very short (e.g. $10 \mathrm{~s}$ ) and relatively small, they were adequately described by straight lines and could be easily recognized in GPS bouts with 5 -min intervals.

\section{Environmental data}

Environmental data were used to explain (additional) variation in high tide travel distance (as described below). Local sea water levels were estimated for every $10 \mathrm{~min}$ by interpolating available tidal gauge data of Waterinfo (Rijkswaterstaat 2018) with the software InterTides (Rappoldt et al. 2014). Wind and temperature data were available for every $10 \mathrm{~min}$ from the KNMI meteorological station located at the north-eastern edge of the Vliehors, roughly $1 \mathrm{~km}$ from the study area $\left(53^{\circ} 15^{\prime} 11^{\prime \prime} \mathrm{N}, 4^{\circ} 56^{\prime} 25^{\prime \prime} \mathrm{E}\right.$; KNMI 2018).

\section{Analysis of immediate displacement}

To quantify the immediate effect of disturbance, we first calculated distances between consecutive GPS measurements. We then selected those measurements that had been labelled with disturbance, together with their single preceding undisturbed (pre-disturbance) measurements (total $n=240$ ). The disturbed movements consisted of 115 flying movements and five walking movements; flying and walking movements did not differ in distance (Wilcoxon signed-rank test: $W=277, p=0.896$ ). The 240 distance measurements were categorised into pre-disturbance $(n=120)$, air force disturbance $(n=35)$, walker disturbance $(n=53)$ and non-anthropogenic disturbance $(n=32)$. A single remaining disturbance caused by a civil airplane (distance $1.6 \mathrm{~km}$ ) was removed from the analysis since it belonged to none of the disturbance source categories. Some movements consisted of more than one GPS fixes $(n=25)$, either because a bird flew a long distance after being disturbed, or because a GPS fix was taken exactly during the moment of flight. In these cases we used the total travel distance within the sequence as the disturbance distance for that event. We performed a Dunn's test (distances were not normally distributed and variances were not homogeneous across categories; Dunn 1961) to compare immediate displacement upon disturbance with pre-disturbance distances and to find significant differences in displacement among disturbance categories.

\section{Analysis of high tide travel distance}

GPS data were also used to quantify longer-term effects of disturbance on travel distance during a high tide period. We first created time windows around all high tides within our observation period, reaching from $2 \mathrm{~h}$ before high tide to $2 \mathrm{~h}$ after. We chose a window size of $4 \mathrm{~h}$ to exclude the possibility that birds would be foraging within a time window (visual inspection of the selected data confirmed that this was never the case). We then selected from all GPS data the bouts that (1) consisted of anywhere between 45 and 51 measurements in those time windows (allowing for up to six missing GPS measurements) and (2) were predominantly during daytime, i.e. more than $33 \%$ of whose GPS measurements were between sunrise and sunset. These bouts represented bird high tides. The Royal Netherlands Air Force provided complete data on air force training times and duration. Combining the selected bouts with the air force training data and our disturbance labelled GPS measurements, we further selected bouts of two types: (1) bouts within which we had labelled any amount of GPS measurements with disturbance by an anthropogenic source, including experimental disturbance ( $n=38$ bouts) and (2) bouts within which we had not labelled any measurements with disturbance by an anthropogenic source and during which no air force training had taken place $(n=225$ bouts). In the second type we also included bouts during which we had been observing partially or not at all, under the assumption that the amount of anthropogenic disturbance was negligible for high tides without air force training (we observed a mere total of eleven anthropogenic disturbances that were caused by sources other than the air force, amounting to 0.013 disturbances per bird per hour). The bouts that resulted from the selection procedure ( $n=263$ bouts or bird high tides) ranged from 11 August to 30 October 2017. For each bout we calculated 
the total travel distance within that bout ("high tide travel distance"). For those bouts that contained GPS measurements labelled with disturbance by an anthropogenic source, we additionally calculated the total distance travelled as an immediate disturbance response within the bout, i.e. the sum of the GPS movements labelled with disturbance ("total immediate displacement"). Finally, we determined the roost (North, Mid or South) in which the bird was located at the start of the bout ("start roost") and the high tide maximum water level on the Vliehors (relative to Amsterdam Ordnance Datum, NAP).

To test which factors explained variation in high tide travel distance, we built a generalised linear mixed model (GLMM) with a gamma response distribution and a log link function. The global model contained the following predictor variables: (1) total immediate displacement, (2) maximum water level, (3) start roost, (4) average temperature, (5) average wind speed and (6) number of GPS measurements constituting the bout. We also included all possible two-way interactions between predictors 1-5. Individual bird $(n=20)$ and individual high tide period $(n=53)$ were included as random effects. Time in the season was not included as it was strongly correlated with average temperature $(r=-0.75)$. Due to the small number of high tides containing disturbance, we did not discriminate between different disturbance sources. A minimal model was obtained by stepwise backward elimination of least significant interaction and main terms, until all terms were significant or part of a significant interaction. In each step, we determined the significance of terms with a likelihood-ratio Chi square test, alternately dropping terms and comparing the model from which they had been dropped to the non-restrictive model they were nested in.

We also wanted to assess whether high tide travel distance varied in addition to the total immediate displacement, i.e. if there was any increase or decrease in movement beyond immediate disturbance responses. We calculated a second response variable, "additional high tide travel distance", defined as high tide travel distance minus total immediate displacement. A positive correlation between total immediate displacement and additional high tide travel distance would suggest that immediate disturbance responses result in additional movements over the high tide timescale, for example due to birds returning to a roost site or staying restless in the hours after disturbance. A negative correlation would suggest that birds stay still after disturbance, while no correlation would suggest that immediate disturbance responses do not influence post-disturbance movement in any way. We modelled additional high tide travel distance with the explanatory variables from the minimal model of the previous section.
Statistical analyses were performed in R version 3.4.3 ( $\mathrm{R}$ Core Team 2017) with use of the packages geosphere (Hijmans 2017) for distance calculation, StreamMetabolism (Sefick 2016) for sunset and sunrise calculation, dunn.test (Dinno 2017) for performing Dunn's tests and Ime4 (Bates et al. 2015) for GLMM fitting.

\section{Energetic costs of disturbance}

We calculated the energetic costs of disturbance at roost sites as a percentage of the daily energy expenditure. Based on our results, we assumed that immediate spatial disturbance effects can be used as a proxy for overall spatial effects in our study system (see Discussion). Therefore we used immediate displacement to calculate overall energetic consequences of spatial disturbance effects. We first calculated the energetic costs of a median air force, walker and non-anthropogenic disturbance, assuming that (1) birds fly on average $12 \mathrm{~m} / \mathrm{s}$ (extracted from speed measurements of our GPS devices), and (2) flying costs are $36 \mathrm{~J} / \mathrm{s}$ (Pennycuick 1989). We then estimated daily energy expenditure due to current levels of anthropogenic and non-anthropogenic disturbance at roost sites. For this we used the disturbance frequencies observed in the field and we assumed that (1) daily energy requirement is $860 \mathrm{~kJ}$ (calculated from Zwarts et al. 1996, given that GPS-tracked birds in our study weighed on average $600 \mathrm{~g}),(2)$ birds roost a total of $12 \mathrm{~h}$ per day and (3) disturbance frequencies at night are equal to the frequency observed during daytime (a highly conservative assumption). Finally, we estimated extra foraging time needed to compensate energy expenditure due to current levels of anthropogenic and non-anthropogenic disturbance at roost sites. For this we assumed that (1) prey energy content is $21.9 \mathrm{~kJ} /(\mathrm{g}$ ash free dry weight) (Zwarts et al. 1996) and (2) average prey intake rate is $1 \mathrm{mg}$ ash free dry weight per second (Zwarts et al. 1996). Disturbance frequency of recreation was based both on walker (nonexperimental) and civil airplanes whereas energetic cost was based only on walker disturbances, since our GPS data contained only one recorded civil airplane disturbance. However, disturbance frequencies of both walker and civil airplane were so small in the study area (see Table 1 and Discussion) that this would have little influence on the interpretation of energy calculations.

\section{Results}

\section{Patterns and sources of disturbance}

In total, we observed disturbances to birds during $181 \mathrm{~h}$ ( 565,000 bird-hours), scoring 51 anthropogenic, 64 non-anthropogenic and 118 experimental disturbances (Table 1). Non-anthropogenic disturbances constituted $62 \%$ of the observed (non-experimental) disturbance frequency. Most non-anthropogenic disturbances 
Table 1 Overview of disturbance in the study area

\begin{tabular}{|c|c|c|c|c|c|}
\hline & $\begin{array}{l}\text { Disturbance source } \\
\text { class }\end{array}$ & Disturbance source & Disturbance events & $\begin{array}{l}\text { Disturbed birds/ } \\
\text { event }^{\mathrm{a}}\end{array}$ & $\begin{array}{l}\text { Disturbance } \\
\text { frequency (per } \\
\text { bird per hour) }\end{array}$ \\
\hline \multirow[t]{6}{*}{ Anthropogenic } & \multirow[t]{3}{*}{ Air force } & Jet fighter & 20 & 800 & 0.028 \\
\hline & & Helicopter & 11 & 230 & 0.004 \\
\hline & & Motor vehicle & 9 & 1110 & 0.018 \\
\hline & \multirow[t]{3}{*}{ Recreation } & Civil airplane & 6 & 680 & 0.007 \\
\hline & & Walker & 5 & 630 & 0.006 \\
\hline & & Total & 51 & 700 & 0.063 \\
\hline \multirow[t]{4}{*}{ Non-anthropogenic } & \multirow[t]{2}{*}{ Bird } & Bird of prey & 8 & 990 & 0.014 \\
\hline & & Non-predatory bird & 14 & 810 & 0.020 \\
\hline & \multirow[t]{2}{*}{ Unknown } & Unknown & 42 & 930 & 0.069 \\
\hline & & Total & 64 & 910 & 0.103 \\
\hline Experimental & & Walker & 118 & 720 & 0.150 \\
\hline
\end{tabular}

${ }^{a}$ Rounded to the nearest 10

had an unknown cause. Military activities (jet fighters, helicopters and motor vehicles) caused most of the observed (non-experimental) anthropogenic disturbances. On average, an individual bird was disturbed 0.17 times per hour (not taking into account experimental disturbances).

\section{Immediate displacement}

Upon being disturbed by any source, birds travelled about fifty times further than they did in the 5-min pre-disturbance interval (Dunn's test: $z>6.73, p<0.001$ for all disturbance categories; Fig. 2). Although not significant, air force disturbances tended to yield larger immediate displacements (median $=341 \mathrm{~m}$ ) than walker (median $=186 \mathrm{~m}$; Dunn's test: $z=1.33, p=0.092$ ) and non-anthropogenic disturbances (median $=168 \mathrm{~m}$; Dunn's test: $z=1.50, p=0.067)$. There was considerable variation in immediate displacement distance after disturbance $\left(\right.$ Q $_{\text {uartile }}=83 \mathrm{~m}$, median $=206 \mathrm{~m}, Q_{3}=416$ $\mathrm{m})$ compared to pre-disturbance movements $\left(Q_{1}=2 \mathrm{~m}\right.$, median $=4 \mathrm{~m}, Q_{3}=19 \mathrm{~m}$; Fig. 2).

\section{High tide travel distance}

Total distance travelled by roosting oystercatchers during a high tide period was in the order of magnitude of a few kilometres $\left(Q_{1}=1.0 \mathrm{~km}\right.$, median $=1.9 \mathrm{~km}$, $Q_{3}=2.9 \mathrm{~km}$ ). High tide travel distance increased with water level, although the extent of increase varied among start roosts $\left(\chi_{\mathrm{df}=2}^{2}=27.04, p<0.001\right.$; Table 2; Fig. 3a). Wind speed slightly reduced the effect of water level on high tide travel distance $(\beta=-0.33 \mathrm{~m} /(\mathrm{m} \cdot \mathrm{s}), \mathrm{SE}(\beta)=0.13$, $\chi_{\mathrm{df}=1}^{2}=5.97, p=0.015$; Table 2). Most importantly, high tide travel distance increased with larger total immediate displacement $\left(\beta=0.50 \mathrm{~m} / \mathrm{m}, \mathrm{SE}(\beta)=0.24, \chi_{\mathrm{df}=1}^{2}\right.$

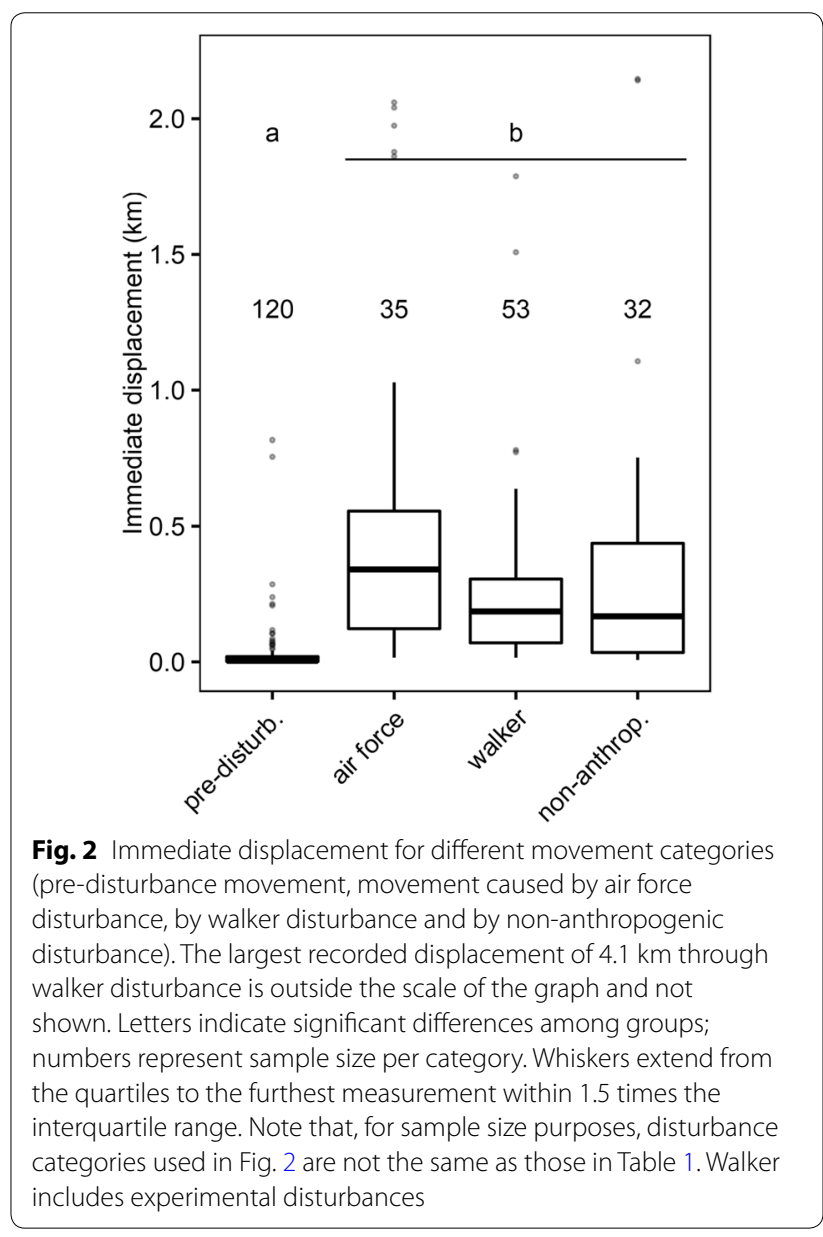

$=4.66, p=0.031$; Table 2; Fig. 3b). However, additional high tide travel distance (high tide travel distance minus total immediate displacement) was not affected by total 
Table 2 Minimal GLMM of high tide travel distance

\begin{tabular}{|c|c|c|c|c|c|}
\hline Fixed effects & $\beta$ & $\mathrm{SE}(\beta)$ & df & $x^{2}$ & $p$ \\
\hline Intercept & -2.00 & 0.59 & & & \\
\hline $\begin{array}{l}\text { Total immediate displacement } \\
(\mathrm{km})\end{array}$ & 0.50 & 0.24 & 1 & 4.66 & 0.031 \\
\hline Maximum water level (m) & 3.18 & 0.63 & & & \\
\hline \multicolumn{6}{|l|}{ Start roost } \\
\hline Mid & 0.96 & 0.38 & & & \\
\hline South & 1.57 & 0.33 & & & \\
\hline Wind speed $(10 \mathrm{~km} / \mathrm{h})$ & 0.18 & 0.15 & & & \\
\hline $\begin{array}{l}\text { Maximum water level } \times \text { wind } \\
\text { speed }\end{array}$ & -0.33 & 0.13 & 1 & 5.97 & 0.015 \\
\hline Maximum water level $\times$ start roost & & & 2 & 27.04 & $<0.001$ \\
\hline Mid & -1.17 & 0.37 & & & \\
\hline South & -1.70 & 0.31 & & & \\
\hline
\end{tabular}

GLMM was created with a gamma response distribution and a log link function. High tide travel distance in $\mathrm{km}$, from $2 \mathrm{~h}$ before high tide to $2 \mathrm{~h}$ after. Variance estimates for random effects individual bird and individual high tide period are 0.03 and 0.07 , respectively. $n=263$ bird high tides

immediate displacement $(\beta=-0.03 \mathrm{~m} / \mathrm{m}, \operatorname{SE}(\beta)=0.24$, $\chi_{\mathrm{df}=1}^{2}=0.02, p=0.902$; Fig. 4; Additional file 1: Table S1).

\section{Energetic costs of disturbance}

We calculated that median air force, recreation and non-anthropogenic disturbances cost $1.02 \mathrm{~kJ}, 0.56 \mathrm{~kJ}$ and $0.50 \mathrm{~kJ}$, respectively, for an individual bird. With the observed disturbance frequencies (Table 1), we calculated the present levels of air force, recreation and non-anthropogenic disturbances at roost sites to increase daily energy expenditure for an individual bird with $0.07 \%, 0.004 \%$ and $0.07 \%$, respectively. We calculated the daily extra foraging time needed to compensate these energy expenditures to be $28 \mathrm{~s}, 2 \mathrm{~s}$ and $28 \mathrm{~s}$, respectively.

\section{Discussion}

Our study combined field observations with GPS tracker data to quantify the effect of anthropogenic disturbance on travel distances of roosting birds in the non-breeding season. We show that, in response to disturbance, oystercatchers move a couple hundred meters. Although not statistically significant, anthropogenic disturbances tended to cause larger responses than non-anthropogenic disturbances. Our results show that disturbance increases the distance travelled during a high tide period. This increase, however, is equal to the sum of immediate displacements due to disturbance in a high tide period, suggesting that the high tide travel distance response to disturbance is constituted solely by the immediate responses. Due to low disturbance frequencies, anthropogenic disturbance at roost sites accounts on average for $0.08 \%$ of the daily energy expenditure of oystercatchers. We discuss these results and their implications for oystercatchers in our study system.

\section{Immediate displacement}

Using GPS trackers we accurately quantified immediate displacement distances upon disturbance. Previous disturbance studies have sometimes included flight
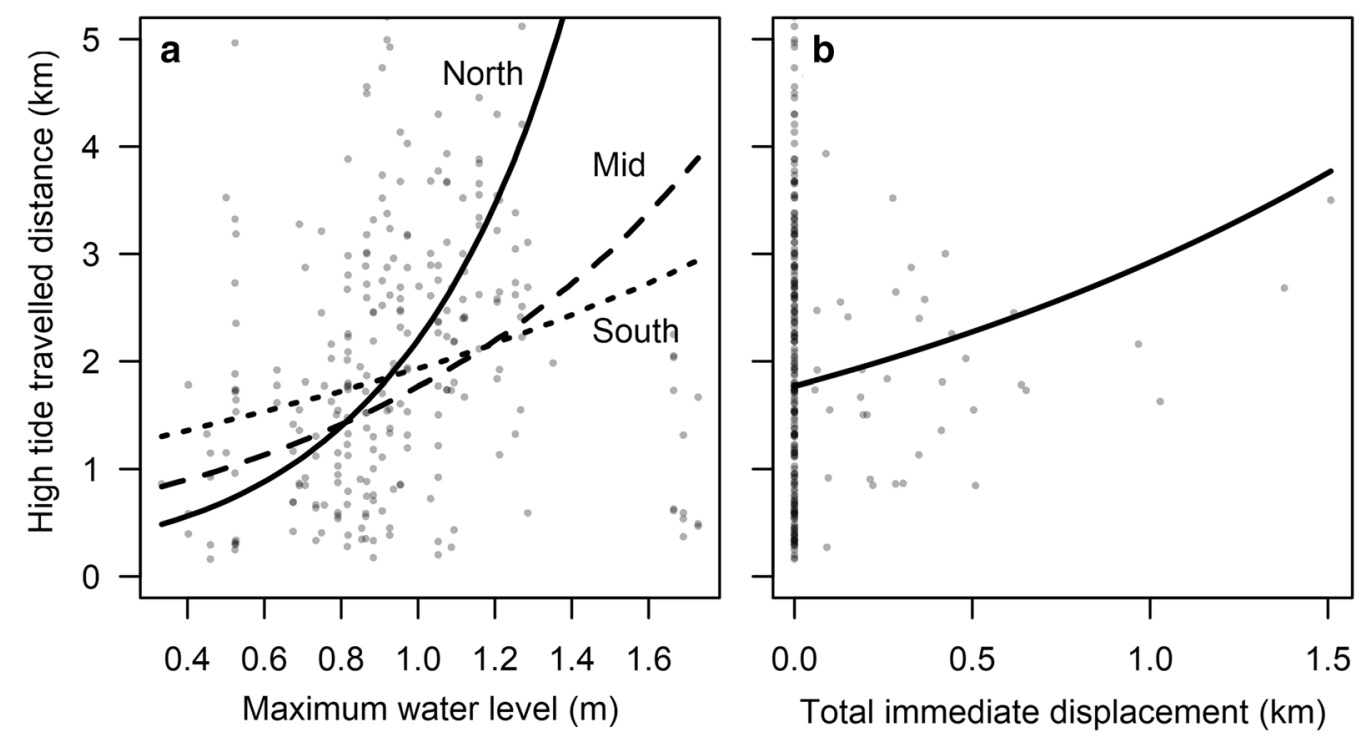

Fig. 3 Relationship between high tide travel distance and (a) maximum water level (maximum water level interacted with roost) and (b) total immediate displacement, within that high tide period. To generate model fits for each effect term, other effect terms were fixed at their mean value. $n=263$ bird high tides for both plots 


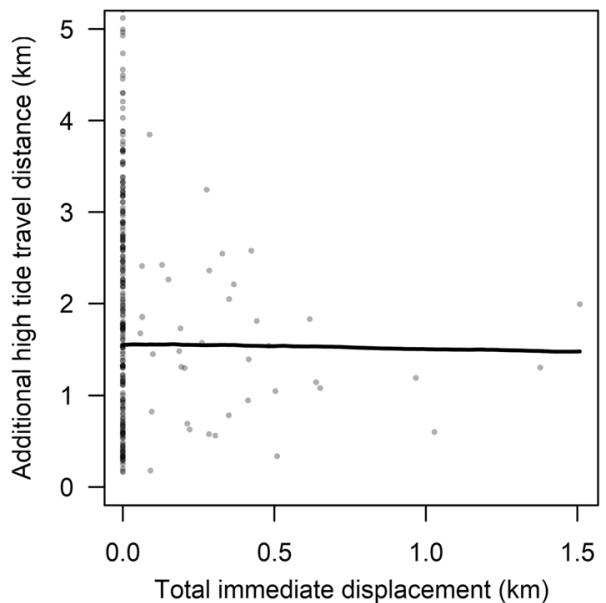

Fig. 4 Relationship between additional high tide travel distance (defined as high tide travel distance minus total immediate displacement) and total immediate displacement. To generate the model fit, other effect terms were fixed at their mean value. $n=263$ bird high tides

distances, but only for one type of disturbance source (Beale and Monaghan 2004) or by classifying flight distance in coarse categories (Kirby et al. 1993; Spaans et al. 1996). Anthropogenic disturbances have been hypothesised more likely to cause large immediate displacements in comparison to non-anthropogenic disturbances (Spaans et al. 1996). Although not significant, our results suggest that anthropogenic disturbances, especially air force, tend to cause larger displacements than nonanthropogenic disturbances. However, we found oystercatcher responses to be highly variable and immediate displacement responses of more than one kilometre were detected for all disturbance sources. We note that our disturbance source categories are coarse and responses may differ among disturbance types within those categories. For example, for aircraft the frequency of occurrence, shape, size, sound, speed and predictability of their flight patterns might be important determinants of bird responses (Smit and Visser 1993) while in our study, both jet fighters and helicopters are binned under "air force".

\section{Immediate versus high tide travel distance responses}

Our results indicate that, in our study system, effects of disturbance on high tide travel distance are confined to immediate disturbance responses. Birds showed no additional movement beyond immediate displacement in response to disturbance (e.g. through flying back to the location of disturbance), nor did they seem to compensate spatially for immediate responses to disturbance (through staying still or moving less after having been disturbed). In our study system, high tide travel distance is strongly influenced by maximum water level since birds roughly follow a back-and-forth trajectory dictated by the upcoming and receding tide. Water advances faster and further inland during tides with a higher maximum water level, forcing birds to make a larger displacement within the high tide period. Upon disturbance, birds were generally observed to move parallel to the waterline and then to continue following their natural trajectory. Given that typical disturbance responses (order of magnitude of several hundred metres) are small enough for birds not to leave the roost site, this would explain why birds neither compensate movement nor show additional movement over a longer timescale in response to disturbance.

It is important to note that the relationship between immediate and longer term responses to disturbance might vary between situations. For example, longerterm responses to disturbance could depend strongly on geographic characteristics. Our study area is a large sand flat without geographical boundaries, extensive parts of which are suitable for birds to roost (Fig. 1). Consequently, GPS-tracked birds flew to another established roost (North, Mid or South) in only 3.3\% of the observed disturbances. However, if a roost site is small and isolated (e.g. a sandbank against a dike), we expect that birds, upon disturbance, are forced to fly to other roost sites more frequently. Flying back to the original preferred roost site after the disturbance is gone would in these cases add double the immediate displacement to the total high tide travel distance. In such instances, maintaining multiple roosts within a network of sites would be important to reduce flight costs following disturbance events. Thus, we expect longer-term effects to be more severe in areas where roost sites are smaller, further apart and more accessible for disturbance sources.

\section{Implications of disturbance}

We argue that the costs of anthropogenic disturbance for roosting oystercatchers are likely to be small in our study area. Displacement due to current levels of anthropogenic disturbance was calculated to require an energy expenditure of $0.08 \%$ of the daily energy requirement for an individual bird, requiring an extra $30 \mathrm{~s}$ of foraging per day to compensate. We believe that our calculations are robust to the assumptions made. For example, our estimate for flight time upon walker disturbance $(15.5 \mathrm{~s})$ is similar to the flight time measured in an earlier study (21.2 s; Collop et al. 2016). Even if travel distances were underestimated two- or threefold in our study due to birds not moving in a perfectly straight line between two location measurements, the impact of disturbed movement on the daily energy budget would still be minimal $(\sim 0.2 \%)$. Moreover, the disturbance frequencies observed in our study area (0.17 disturbances per hour, excluding 
experimental disturbance) are under the modelled critical disturbance thresholds that were predicted to reduce survival in wintering oystercatchers $(0.2-0.5$ disturbances per hour under conditions with harsh weather and low food availability) (Goss-Custard et al. 2006).

We note that our energy calculations are based on average displacement responses of roosting oystercatchers on Vlieland, incorporating only a limited set of conditions. Bird species show great variability in responses to disturbance (Kirby et al. 1993; Smit and Visser 1993; Laursen et al. 2005; Collop et al. 2016), with larger species generally being more easily disturbed than smaller ones (Laursen et al. 2005; Collop et al. 2016). We observed that, in our study area, oystercatchers are far less susceptible to disturbance than Eurasian Curlews (Numenius arquata, 1.6 times as many disturbances per bird per hour) and especially Bar-tailed Godwits (Limosa lapponica, 4.6 times as many disturbances per bird per hour) (van der Kolk et al. unpublished data). Thus, we emphasize that interspecific variability is crucial when deriving conclusions from disturbance case studies (Blumstein et al. 2005).

Furthermore, the occurrence and character of potential disturbance sources differs per site. Our study area may not be representative of other inter-tidal areas in that human presence is limited because of military activity. Indeed, our estimated disturbance frequency is over four times lower than the average 0.78 disturbances per hour reported for roosting oystercatchers based on observations on nine different roost sites in the Netherlands (Spaans et al. 1996). In our study, disturbances associated with recreation (e.g. walkers, dogs) were rare $(<10 \%$ of total non-experimental disturbance frequency for an individual bird) and the energy costs of such disturbances are likely higher on many other roosts. Jet fighters, on the other hand, were present on a near-daily basis (during our fieldwork period, air force trainings were held on $65 \%$ of the weekdays, amounting to $1.4 \mathrm{~h}$ of training on average per weekday). Jet fighters could therefore be hypothesised to impact roosting birds negatively (as they have been previously; Smit and Visser 1993; Koffijberg et al. 2003, 2005; Bouten and Ens 2006; Laursen et al. 2009; Blew et al. 2017). However, jet fighters rarely caused disturbance, suggesting that roosting birds in the study area are not highly susceptible to the activity as a result of the repetition and predictability of the jets' patterns (habituation to air force activity has been suggested for the Vliehors and other locations in the Wadden Sea (Teunissen 1991; Smit and Visser 1993; Smit 2004).

Finally, it is important to note that our dataset does not include some occasional but very strong disturbance sources. From oystercatcher GPS data we observed that large transport aircraft (which occur approximately three times a year, but not during our observations) cause a much greater flight response than does usual air traffic. Such sources, although rare, are thus likely to yield much higher energetic costs per disturbance and research is ongoing to understand how flight responses vary amongst different disturbance sources.

\section{Future outlook}

We recommend additional studies of the longer-term spatial effects of disturbance on shorebird communities, especially given that effects may vary strongly among sites, disturbance sources and species. We suggest that GPS techniques are an effective means for this since they allow for further exploration of spatial effects, for example by analysing even longer timescales (multiple days) or linking travel distance to foraging time in subsequent low tide periods (see Verhulst et al. 2001; Stillman and Goss-Custard 2002). By modelling disturbance effects on energy budgets more comprehensively, eventual impacts on survival and population dynamics could be assessed (Goss-Custard et al. 2006). A broader understanding of these impacts will be important for future decision-making for the conservation and management of shorebird populations.

\section{Conclusions}

We present an example of longer-term spatial responses to disturbances being similar to immediate responses. Although we are aware that our results should be treated with caution, our study indicates that at least in some cases longer-term spatial responses of disturbance can be derived from immediate responses. Under the observed conditions, disturbance frequencies of roosting oystercatchers on the Vliehors are so low that the effect on energy expenditure is minimal.

\section{Supplementary information}

Supplementary information accompanies this paper at https://doi. org/10.1186/s40657-019-0171-8.

Additional file 1: Table S1. Minimal GLMM of additional high tide trave distance (high tide travel distance minus total immediate displacement; in $\mathrm{km}$ ).

\section{Acknowledgements}

We thank everybody involved in catching, tagging and observing birds, especially Kees Oosterbeek, Symen Deuzeman and Laurens van Kooten. We thank the air force department on Vlieland for logistical support in and around the study area. We thank three anonymous reviewers for their valuable comments which improved the paper. We acknowledge the feedback provided by ecologists working at the institutes involved (see Funding) during half-yearly meetings. UvA-BiTS studies are facilitated by infrastructures for e-Science, developed with support of the NLeSC (https://www.esciencecenter.com) 
and carried out on the Dutch national e-infrastructure with support of SURF Foundation.

\section{Authors' contributions}

$\mathrm{HL}$ and $\mathrm{HK}$ designed the study. $\mathrm{HL}$ and $\mathrm{MJ}$ collected field data, with support of KK and HK. HL performed the data analysis, with support of HK, MP and AA. $\mathrm{HL}$ wrote the manuscript, with support of HK, MP and all authors providing critical feedback. All authors read and approved the final manuscript.

\section{Funding}

Funding was provided by the Applied and Engineering Sciences domain of the Netherlands Organisation for Scientific Research (NWO-TTW 14638) and by the Royal Netherlands Air Force, Birdlife Netherlands, NAM gas exploration, and Deltares.

\section{Availability of data and materials}

Data will be made available in the Dryad Digital Repository (https://doi. org/10.5061/dryad.74vm25v).

\section{Ethics approval and consent to participate}

Tagging of oystercatchers was done under license of the Dutch Flora and Fauna Law (FF/75A/2013/038) and the Natuurbeschermingswet (Province of Friesland, 801233) and approved by the Dutch Ethical Committee (Sovon AVD25002015200-001)

\section{Consent for publication}

\author{
Not applicable.
}

\section{Competing interests}

Karen L. Krijgsveld is employed by the Royal Netherlands Air Force, which is one of the organisations causing disturbance in the study area. The other authors declare that they have no competing interests.

\section{Author details}

1 Department of Animal Ecology, Netherlands Institute of Ecology, 6708PB Wageningen, The Netherlands. ${ }^{2}$ Resource Ecology Group, Wageningen University \& Research, 6708PB Wageningen, The Netherlands. ${ }^{3}$ Centre for Avian Population Studies, Droevendaalsesteeg 10, 6708PB Wageningen, The Netherlands. ${ }^{4}$ Department of Animal Ecology and Physiology, Radboud University, 6500GL Nijmegen, The Netherlands. ${ }^{5}$ Sovon-Texel, Sovon Dutch Centre for Field Ornithology, 1790AB Den Burg, The Netherlands. ${ }^{6}$ Nature Bureau, Royal Netherlands Air Force, 4820BB Breda, The Netherlands.

Received: 21 December 2018 Accepted: 15 August 2019

Published online: 22 August 2019

\section{References}

Ackerman JT, Takekawa JY, Kruse KL, Orthmeyer DL, Yee JL, Ely CR, et al. Using radiotelemetry to monitor cardiac response of free-living tule greater white-fronted geese (Anser albifrons elgasi) to human disturbance. Wilson J Ornithol. 2004;116:146-51.

Bates D, Maechler M, Bolker B, Walker S. Fitting linear mixed-effects models using Ime4. J Stat Softw. 2015;67:1-48.

Beale CM, Monaghan P. Behavioural responses to human disturbance: a matter of choice? Anim Behav. 2004;68:1065-9.

Bjarnason JB, Günther W, Revier H. Tourism. In: Kloepper S, et al., editors. Wadden Sea quality status report 2017. Wilhelmshaven, Germany: CWSS; 2017.

Blew J, Günther K, Hälterlein B, Kleefstra R, Laursen K, Scheiffarth G. Trends of migratory and wintering waterbirds in the Wadden Sea 1987/1988-2013/2014. Wadden Sea Ecosystem No. 37. Wilhelmshaven, Germany: CWSS; 2016.

Blew J, Gunther K, Halterlein B, Kleefstra R, Laursen K, Ludwig J, et al. Migratory birds. In: Kloepper S, et al., editors. Wadden Sea quality status report 2017. Wilhelmshaven: CWSS; 2017.

Blumstein DT, Fernández-Juricic E, Zollner PA, Garity SC. Inter-specific variation in avian responses to human disturbance. J Appl Ecol. 2005;42:943-53.
Bouten W, Ens BJ. Effecten van vliegoefeningen op de Vliehors: kansen voor een planningsinstrument om de verstoring van vogels te minimaliseren. SOVON-rapport 2006/08. Nijmegen: Sovon; 2006.

Bouten W, Baaij EW, Shamoun-Baranes J, Camphuysen KC. A flexible GPS tracking system for studying bird behaviour at multiple scales. J Ornithol. 2013;154:571-80

Brandt AC, Wollesen A. Tourism and Recreation. Thematic Report No. 3.4. In: Marencic H, de Vlas J, editors. Wadden Sea quality status report 2009. Wadden Sea Ecosystem No. 25. CWSS: Wilhelmshaven; 2009.

Collop C, Stillman RA, Garbutt A, Yates MG, Rispin E, Yates T. Variability in the area, energy and time costs of wintering waders responding to disturbance. Ibis. 2016;158:711-25.

Dinno A. dunn.test: Dunn's test of multiple comparisons using rank sums. $\mathrm{R}$ package version 1.3.5; 2017.

Dunn OJ. Multiple comparisons among means. J Am Stat Assoc. 1961;56:52-64

Finney SK, Pearce-Higgins JW, Yalden DW. The effect of recreational disturbance on an upland breeding bird, the golden plover Pluvialis apricaria. Biol Conserv. 2005;121:53-63.

Fitzpatrick S, Bouchez B. Effects of recreational disturbance on the foraging behaviour of waders on a rocky beach. Bird Study. 1998;45:157-71.

Gill JA. Approaches to measuring the effects of human disturbance on birds. Ibis. 2007;149(s1):9-14.

Gill JA, Sutherland WJ, Watkinson AR. A method to quantify the effects of human disturbance on animal populations. J Appl Ecol. 1996;33:786-92.

Gill JA, Norris K, Sutherland WJ. Why behavioural responses may not reflect the population consequences of human disturbance. Biol Conserv. 2001;97:265-8

Glover HK, Weston MA, Maguire GS, Miller KK, Christie BA. Towards ecologically meaningful and socially acceptable buffers: response distances of shorebirds in Victoria, Australia, to human disturbance. Landsc Urban Plan. 2011;103:326-34.

Goss-Custard JD, Triplet P, Sueur F, West AD. Critical thresholds of disturbance by people and raptors in foraging wading birds. Biol Conserv. 2006;127:88-97.

Hijmans RJ. Geosphere: spherical trigonometry. R package version 1.5-7; 2017.

Hofstede J, Hähne K, Oost A, Piontkowitz T, Raagaard K, Schans H, et al. Human activities. In: Essink K, Dettmann C, Frake H, Laursen K, Lüerßen G, Wiersinga WA, editors. Wadden Sea quality status report 2004. Wadden Sea Ecosystem No. 19. CWSS: Wilhelmshaven; 2005. p. 27-74.

Kirby JS, Clee C, Seager V. Impact and extent of recreational disturbance to wader roosts on the Dee estuary: some preliminary results. Wader Study Group Bull. 1993;68:53-8.

Klein ML, Humphrey SR, Percival HF. Effects of ecotourism on distribution of waterbirds in a wildlife refuge. Conserv Biol. 1995;9:1454-65.

KNMI. Klimatologie: Informatie over Het Weer in het Verleden. De Bilt, Netherlands. 2018. http://projects.knmi.nl/klimatologie. Accessed 1 Feb 2018.

Koffijberg K, Blew J, Eskildsen K, Günther K, Koks B, Laursen K, et al. High tide roosts in the Wadden Sea: a review of bird distribution, protection regimes and potential sources of anthropogenic disturbance. Wadden Sea Ecosystem No. 16. CWSS: Wilhelmshaven; 2003.

Koffijberg K, Dijksen L, Hälterlein B, Laursen K, Potel P, Südbeck P, et al. Birds. In: Essink K, Dettmann C, Frake H, Laursen K, Lüerßen G, Wiersinga WA, editors. Wadden Sea quality status report 2004. Wadden Sea Ecosystem No. 19. CWSS: Wilhelmshaven; 2005. p. 273-304.

Koffijberg K, Cremer JSM, de Boer P, Nienhuis J, Schekkerman H, Oosterbeek $\mathrm{K}$, et al. Broedsucces van kustbroedvogels in de Waddenzee: Resultaten 2015-2016 en trends in broedsucces in 2005-2016. SOVON-rapport 2017/66. Sovon: Nijmegen; 2017.

Laursen K, Kahlert J, Frikke J. Factors affecting escape distances of staging waterbirds. Wildlife Biol. 2005;11:13-9.

Laursen K, Blew J, Ens B, Eskilden K, Günther K, Hälterlein B, et al. Migratory birds. In: Marencic H, de Vlas J, editors. Wadden Sea quality status report 2009. Wadden Sea Ecosystem No. 25. CWSS: Wilhelmshaven; 2009.

Lord A, Waas JR, Innes J, Whittingham MJ. Effects of human approaches to nests of northern New Zealand dotterels. Biol Conserv. 2001;98:233-40.

Martín B, Delgado S, Cruz A, Tirado S, Ferrer M. Effects of human presence on the long-term trends of migrant and resident shorebirds: evidence of local population declines. Anim Conserv. 2014;18:73-81.

Nisbet IC. Disturbance, habituation, and management of waterbird colonies. Waterbirds. 2000:23:312-32. 
Pennycuick CJ. Bird flight performance: a practical calculation manual. Oxford: Oxford University Press; 1989.

R Core Team. R: a language and environment for statistical computing. Vienna: R Foundation for Statistical Computing; 2017.

Rappoldt C, Roosenschoon OR, van Kraalingen DWG. InterTides, maps of the intertidal by interpolation of tidal gauge data. EcoCurves-rapport 19, Haren: EcoCurves BV; 2014.

Reineking B, Sudbeck P. Seriously declining trends in migratory waterbirds: causes - concerns - consequences. In: Proceedings of the international workshop on 31 August 2006 in Wilhelmshaven, Germany. Wadden Sea Ecosystem No. 23. CWSS: Wilhelmshaven; 2007.

Rijkswaterstaat. Directorate-general for public works and water management, Utrecht, Netherlands. 2018. http://waterinfo.rws.nl. Accessed 10 Jan 2018.

Sefick Jr S. Stream metabolism: a package for calculating single station metabolism from diurnal oxygen curves. R package version 1.1.2; 2016.

Smit CJ. Vervolgonderzoek naar de gevolgen van de uitbreiding van het aantal vliegbewegingen van Den Helder Airport. Alterra-rapport No. 1025. Wageningen, Netherlands: Alterra; 2004.

Smit CJ, Visser GJ. Effects of disturbance on shorebirds: a summary of existing knowledge from the Dutch Wadden Sea and Delta. Wader Study Group Bull. 1993;68:6-19.

Spaans B, Bruinzeel L, Smit CJ. Effecten van verstoring door mensen op wadvogels in de Waddenzee en de Oosterschelde. IBN-rapport No. 202. Instituut voor Bos- en Natuuronderzoek: Den Burg; 1996.

Stillman RA, Goss-Custard JD. Seasonal changes in the response of oystercatchers Haematopus ostralegus to human disturbance. J Avian Biol. 2002:33:358-65.
Teunissen WA. De uitstralingseffecten van geluidsproduktie van de militaire $25 \mathrm{~mm}$ schietbaan in de Marnewaard op plaatskeuze en gedrag van watervogels in het Lauwersmeergebied binnendijks. RIN-rapport No. 91/2. Rijksinstituut voor Natuurbeheer: Arnhem; 1991.

Thaxter CB, Ross-Smith VH, Clark JA, Clark NA, Conway GJ, Marsh M, et al. A trial of three harness attachment methods and their suitability for long-term use on Lesser Black-backed Gulls and Great Skuas. Ring Migrat. 2014;29:65-76.

van de Kam J, Ens BJ, Piersma T, Zwarts L. Ecologische atlas van de Nederlandse wadvogels. Haarlem: Schuyt \& Co.; 1999.

van de Pol M, Atkinson P, Blew J, Crowe O, Delany S, Duriez O, et al. A global assessment of the conservation status of the nominate subspecies of Eurasian oystercatcher Haematopus ostralegus ostralegus. Int Wader Stud. 2014;20:47-61.

van Roomen M, van Turnhout C, Blew J, Koffijberg K, Nagy S, Citegetse G, et al. East Atlantic flyway. In: Kloepper S, et al., editors. Wadden sea quality status report 2017. Wilhelmshaven: CWSS; 2017.

Verhulst S, Oosterbeek K, Ens BJ. Experimental evidence for effects of human disturbance on foraging and parental care in oystercatchers. Biol Conserv. 2001;101:375-80.

Walker BG, Boersma PD, Wingfield JC. Field endocrinology and conservation biology. Integr Comp Biol. 2005:45:12-8.

Zwarts L, Ens BJ, Goss-Custard JD, Hulscher JB, Kersten M. Why oystercatchers Haematopus ostralegus cannot meet their daily energy requirements in a single low water period. ARDEA. 1996;84A:269-90.
Ready to submit your research? Choose BMC and benefit from:

- fast, convenient online submission

- thorough peer review by experienced researchers in your field

- rapid publication on acceptance

- support for research data, including large and complex data types

- gold Open Access which fosters wider collaboration and increased citations

- maximum visibility for your research: over 100M website views per year

At BMC, research is always in progress.

Learn more biomedcentral.com/submissions 